\section{American Geophysical Union}

The American Geophysical Union, established in 1919 as the American National Committee of the International Union for Geodesy and Geophysics, held its annual congress this year at Washington, on April 26-28, and one of its sections met again at Berkeley, California, on June 20-21. All the seven sections of the Union, for geodesy, seismology, meteorology, terrestrial magnetism and electricity, oceanography, volcanology, and hydrology, met at Washington. Only the hydrology section was represented at Berkeley, where its meetings were associated with the Western Inter-State Snow Survey Conference. The report of the Union is this year published in two volumes (reproduced direct from typescript, as in recent years), of which the first, of 257 pages, relates to the General Assembly and the first six sections; the second volume is still larger, of 370 pages, and forms a striking illustration of the attention now being devoted in the United States to the many aspects of hydrology - a subject almost neg. lected in Great Britain. The volumes contain very many short scientific papers of great interest, as well as formal reports on work in progress.

\section{Mining Research at Birmingham}

WE have received the report of the work of the Mining Research Laboratory in the University of Birmingham during the year 1933, which has again been financed by the British Colliery Owners' Research Association and by the Miners' Welfare Fund. This executive board of mining research is doing excellent work under the chairmanship of Dr. J. S. Haldane. Again this year silicosis is investigated, but in accordance with Dr. Haldane's repeatedly expressed opinions, the work appears to be confined to the determination of 'free' silica; Dr. W. Jones's investigations are not referred to. Nystagmus, which was carefully investigated previously, is not specially discussed, although the investigation of underground illumination no doubt will play a very important part in minimising the incidence of this distressing and costly complaint. Much appears to have been done with regard to the production of gas of high calorific power from coal or coke oven gas, and various investigations tending to improve atmospheric conditions underground as well as investigations into the physiology of the miner will no doubt prove of great value in the future.

\section{Calculations for Draughtsmen}

THE Association of Engineering and Shipbuilding Draughtsmen has recently added to its useful series of pamphlets one on "Some Notes on Deflection", by Mr. W. R. Thomson, and another on "Mechanical Design of High-Speed Salient-Pole A.C. Rotors", by W. R. Needham. In the first of these the author gives a logical account of the principles of deflection of cantilevers and simply supported beams. No advanced mathematics is used, rough sketches being sufficient to give the figures necessary for the deflection calculations, which are made by slide rule. In the second pamphlet, Mr. Needham deals with shafts and bearings, shaft stresses, critical speeds, rotor bodies, rotor poles, coil supports and balancing. The stresses in high-speed rotors are of a very high order, and the centrifugal force of a single pole and coil, says the author, at the overspeed may exceed a million and a half pounds. The overspeed in some hydro-electric machines may exceed the normal by as much as 100 per cent.

\section{Bibliography of Seismology}

A NEw volume (No. 12) of the Publications of the Dominion Observatory (Ottawa) is, we are informed, to be devoted to the bibliography of seismology. The first part, issued recently, contains notices of memoirs for the first quarter of the present year. It may be noted that vol. 10 of the Publications includes the titles of 2,000 memoirs for the years 1929-33. A still earlier series, in which notices of 1,200 memoirs appeared, was issued under the auspices of the Eastern Section of the Seismological Society of America and was published in vol. 17-19 of the Bulletin of the Society. Both series were prepared by the present editor, Mr. E. A. Hodgson, who has now the assistance of twenty-four collaborators. All the important countries in which earthquakes are studied are represented on this list, with the exception, we regret to notice. of Great Britain.

\section{Diseases of Swedes}

A NEw bulletin (No. 74) issued by the Ministry of Agriculture (H.M. Stationery Office, 1s.) is concerned with two diseases of swedes. Experiments with pure culture have shown that canker, which affects the seed-bearing plant, and dry rot which attacks the roots, are both due to the same fungus, Phoma Lingam. This fact is of importance, as infected seed would be likely to result in an infected root crop. The disease is not serious in England, but has become prevalent in New Zealand; and since most of the seed used there is obtained from Great Britain the question of infection is important. Methods of seed sterilisation have been sought with no great success, but evidence has been obtained that weeds afford a serious source of infection. Good cultivation would, therefore, seem as necessary as clean seed if spread of the infection is to be avoided.

\section{Population Problems}

The third General Assembly of the International Union for the Scientific Investigation of Population Problems will be held in Berlin on September 9, at 11 a.m., in the rooms of the University. An International Congress will be held in Berlin on September 10-15 under the auspices of the International Union. The Congress will have the following divisions: (1) Population Statistics; (2) Biology and Race Hygiene; (3) Social, Economic and Psychological Problems of Population ; (4) Medicine and Hygiene. The business office of the Congress is, Berlin W 62, Einemstrasse 11.

\section{Congress of Anthropology}

THE sixteenth Congress of Anthropology and Prehistoric Archæology will be held at Brussels from 
September 1-8. It will consist of the following sections : morphological and functional anthropology, blood groups, human palæontology, heredity and selection, psycho-sociology, criminal anthropology, ethnography, folk-lore and history of religions. Further information can be obtained from the general secretary, Dr. Dekeyser, 9 rue des Sablons, Brussels.

\section{The Sky in May}

Venus continues to be a brilliant evening object. Both its brilliance and its eastern elongation are still increasing. Mars passed through opposition on April 6, and is now an evening object. It will be stationary on May 19. The planet is very conspicuous in the southern sky just before midnight. Mars has been very close to $\gamma$ Virginis during the last week in April. This star is worth examining with a small telescope as it is a double star which is easily resolved, the two components, whose magnitudes are $3^{\mathrm{m}} 65$ and $3^{\mathrm{m}} 68$, being six seconds of arc apart. Jupiter is in opposition on May 10. The planet is rather far south of the equator. Saturn is still a morning object. The moon will occult the bright star $\delta$ Geminorum on May 7. Both disappearance and reappearance will be visible at Greenwich, taking place at $21^{\mathrm{h}} 59^{\mathrm{m}}$ and $22^{\mathrm{h}} 56^{\mathrm{m}}$ G.M.T. respectively.

\section{Announcements}

Prof. A. C. Seward, professor of botany in the University of Cambridge, has been elected a member of the Norwegian Academy of Science and Letters, and also an honorary fellow of the Indian Academy of Sciences, Bangalore.

As a token of their admiration, the friends of Sir Arthur Evans in the Mediterranean have subscribed towards the cost of a portrait-bust of himself to be presented to him in recognition of his pioneer work in the exploration of the Mediterranean bronze age civilisation at Knossos. The presentation took place on April 14 in the Museum at Candia in the presence of a numerous body of friends and admirers.

THE thirteenth award of the Faraday Medal of the Institution of Electrical Engineers will be presented to Dr. F. B. Jewett, of New York, at the ordinary meeting of the Institution to be held on May 2. The presentation will precede the twentysixth Kelvin Lecture, which will be delivered by Sir William Bragg, on "The Molecular Structure of Dielectrics".

THE forty-first James Forrest Lecture of the Institution of Civil Engineers will be delivered on May 14 by Prof. O. T. Jones, Woodwardian professor of geology in the University of Cambridge, who will speak on "Geophysics".

The Royal Geographical Society has made the following awards for 1935: Murchison Grant, to Mr. R. P. Bishop, for his surveys in British Columbia and other services to geography; Back Grant to
Mr. Wilfred Thesiger, for his journey through the Danakil country, 1933-34 ; Cuthbert Peek Grant to Mr. A. R. Glen, for his work in Spitsbergen, particularly his leadership of the Oxford University Expedition, 1933 ; Gill Memorial to Mr. E. E. Shipton, for his plane-table surveys of the inner Nanda Devi basin and the neighbouring watersheds.

Prof. W. L. Bragg will deliver the twenty-fifth annual May Lecture to the Institute of Metals on May 8 in the hall of the Institution of Mechanical Engineers, Storey's Gate, Westminster, S.W.1, at 8 p.m. The subject of Prof. Bragg's lecture will be "Atomic Arrangements in Metals and Alloys". Tickets of admission can be obtained from the Secretary of the Institute of Metals, 36 Victoria Street, London, S.W.1.

Drs. Achard, Lapicque and Mayer of Paris, Policard of Lyons and Bouin and Viès of Strasbourg have been elected members of the section of biological sciences in the French Superior Council of scientific research, and Drs. Martin, director of Institut Pasteur, and Roussy, of the faculty of medicine of Paris, extraordinary members.

The August Forel foundation of the German Academy of Natural Sciences at Halle, which is to award a prize every two years for researches in the subjects in which Forel was specially interested (eugenics, the alcohol problem, study of ants and the central nervous system), has recently made its first award to Dr. Graf, who is head of the department of industrial physiology at the Kaiser Wilhelm Institute of Dortmund.

An index to the Astrophysical Journal covering the issues of January 1920-June 1932 (vols. 51-75) will be published in May. It can be obtained, price 2.60 dollars, including postage, from the University of Chicago Press, 5750 Ellis Avenue, Chicago, Illinois.

Applications are invited for the following appointments, on or before the dates mentioned :-A lecturer in zoology in the University of Capetown-The Secretary to the High Commissioner of the Union of South Africa, Trafalgar Square, London, W.C.2 (April 30). A lecturer in the Engineering Department, College of Technology, Leicester-The Registrar (May 4). A junior scientific officer in the Scientific Research Pool, Air Ministry-Chief Superintendent, Royal Aircraft Establishment, South Farnborough, Hants (May 4). A temporary engineering assistant in the Directorate of Works, War Office-The Under-Secretary of State (C.5), The War Office, S.W.1 (May 6). Inspectors in connexion with Agricultural and Horticultural Education and Research under the Ministry of Agriculture and FisheriesThe Secretary, Ministry of Agriculture and Fisheries, 10 Whitehall Place, London, S.W.1 (May 13). A physicist in the Radium and X-Ray Therapeutic Departments of the General Infirmary, Leeds--The Secretary (May 18). A lecturer in mathematics at the Royal Technical College, Glasgow-The Secretary. 